\title{
Standardization of Sucrose and 6-Benzyl Aminopurine for in vitro Micro Tuberization of Potato
}

\author{
Md. Afzal Hossain ${ }^{1}$, Md. Abu Kawochar ${ }^{2}$, Abdullah-Al-Mahmud ${ }^{3 *}$, Ebna Habib Md. Shofiur \\ Rahaman $^{3}$, Md. Altaf Hossain ${ }^{2}$, Khondoker Md. Nasiruddin ${ }^{4}$ \\ ${ }^{1}$ Ministry of Environment \& Forests, Bangladesh Secretariat, Bangladesh \\ ${ }^{2}$ Tuber crops research Centre (TCRC), Bangladesh Agricultural Research Institute, Joydebpur, Gazipur, Bangladesh \\ ${ }^{3}$ International Potato Centre (CIP), SWCA, Banani, Dhaka, Bangladesh \\ ${ }^{4}$ Department of Biotechnology, Bangladesh Agricultural University, Bangladesh
}

Email address:

Mafzalhossain@yahoo.com (Md. A. Hossain),A.Mahmud@cgiar.org (Abdullah-Al-Mahmud)

\section{To cite this article:}

Md. Afzal Hossain, Md. Abu Kawochar, Abdullah-Al-Mahmud, Ebna Habib Md. Shofiur Rahaman, Md. Altaf Hossain, Khondoker Md. Nasiruddin. Standardization of Sucrose and 6-Benzyl Aminopurine for in vitro Micro Tuberization of Potato. American Journal of Agriculture and Forestry. Vol. 3, No. 2, 2015, pp. 25-30. doi: 10.11648/j.ajaf.20150302.13

\begin{abstract}
In vitro micro tuberization from regenerated plantlets of potato varieties was observed in Biotechnology Laboratory, Department of Biotechnology, Bangladesh Agricultural University. Tubers of potato cultivars Diamant and Cardinal were used as initial experimental materials for meristem culture. The experiment was consisted of three factors; variety (Diamant, Cardinal), sucrose concentration $(3 \%, 6 \%, 9 \%, 12 \%)$ and 6-benzyl aminopurine (BAP) levels $\left(2.5,5.0,7.5 \mathrm{mg} \mathrm{L}^{-1}\right)$. As a whole, 24 treatments were laid out in complete randomized design with three replications. Among the varieties, Diamant required minimum days (6-17) for micro-tuber initiation, produced more number of micro-tubers (4.97) and produced more average weight of micro-tuber $(120.39 \mathrm{mg})$ but there had no significant difference. Among the sucrose levels, quickest (6-15 days) micro-tuber initiation, the highest number of micro-tubers vial ${ }^{-1}$ (5.06) and the highest average weight of micro-tuber (137.31 mg) were found in 9\% sucrose level. For different BAP levels, quickest (6-15 days) micro-tuber initiation, the highest number of micro-tubers vial $^{-1}(5.38)$ and the highest average weight of micro-tuber $(126.31 \mathrm{mg})$ were found at $5.0 \mathrm{mg} \mathrm{L}^{-1}$. The best combination for minimum duration (6-8 days) of micro-tuber initiation, the highest number of micro-tubers vial ${ }^{-1}$ (6.00) and the highest average weight of micro-tuber $(152.01 \mathrm{mg})$ was in Diamant with $9 \%$ sucrose at $5 \mathrm{mg} \mathrm{L}^{-1}$. Concomitantly, the lowest number micro-tubers vial ${ }^{-1}(2.00)$ and the lowest average weight of micro-tuber $(89.98 \mathrm{mg})$ were found in Cardinal cultured with $3 \%$ sucrose media where at $7.5 \mathrm{mg} \mathrm{L}^{-1} \mathrm{BAP}$ and at $2.5 \mathrm{mg} \mathrm{L}^{-1} \mathrm{BAP}$, respectively.
\end{abstract}

Keywords: 6-Benzyl Aminopurine, Microtuberization, Plantlets, Potato

\section{Introduction}

Potato (Solanum tuberosum L.) is an important vegetables crop and is grown in winter only in Bangladesh [15]. Microtubers have become an important mode of rapid multiplication for seed tuber of potato [21]. These micro-tubers are utilized for minitubers production in greenhouse or screen house. Wherever microtuber and minituber production technologies have been implemented, they have halved the field time necessary for conventional method to supply to the commercial growers. Microtubers from meristem grown and/or regenerated microplants are now produced and used in Australia, Brazil, Chile, China, Ecuador, India, Indonesia, Kenya, Korea, Peru, Philippines, Taiwan,
UK, Vietnam and even in Bangladesh as disease free seed [7]. However, the technique is controlled by various physical (light, temperature etc.) and chemical (growth regulators) factors. Among the media components, sucrose played an important role in the induction and development of potato microtubers on in vitro [10] and BAP promoted initiation and growth of micro-tubers [19]. Various sucrose concentrations were tested in the microtuber induction medium where the best results were obtained with $8 \%$ [12], with $10 \%$ [3], with $12 \%$ [20], with $9 \%$ and $12 \%$ [13] and with $8 \%$ and $12 \%$ [18]. Tuber induction medium combined with $9 \%$ sucrose promoted tuberization and increased microtuber weight more than the 
tuber induction medium combined with $6 \%$ sucrose, BAP and CCC [11]. Better micro-tuber yield was obtained with $6 \%$ sucrose and $5 \mathrm{mg} \mathrm{L}^{-1}$ BAP under complete dark condition [1]. Microtuber number and fresh weight were greatest with $10 \mathrm{mg}$ $\mathrm{L}^{-1} \mathrm{BAP}$ in presence of $6 \%$ sucrose [16]. Best response to both initiation and production of microtubers were observed in modified MS media containing $5.0 \mathrm{mg} \mathrm{L}^{-1} \mathrm{BAP}$ with $500 \mathrm{mg}$ $\mathrm{L}^{-1} \mathrm{CCC}[6]$ and by using $500 \mathrm{mg} \mathrm{L}^{-1} \mathrm{CCC}$ together with 5.0 $\mathrm{mg} \mathrm{L}^{-1}$ BAP[9]. Therefore, the present investigation was undertaken to find out the appropriate doses of sucrose and growth regulators and their combination(s) with potato varieties for rapid microtuberization.

\section{Materials and Methods}

\subsection{Design and Treatments of the Experiment}

The experiment was carried out in Biotechnology Laboratory, Department of Biotechnology, Bangladesh Agricultural University. The experiment was consisted of three factors; variety (Diamant, Cardinal), sucrose levels (3\%, $6 \%, 9 \%, 12 \%)$ and BAP levels $\left(2.5,5.0,7.5 \mathrm{mg} \mathrm{L}^{-1}\right)$. As a whole, 24 were laid out in complete randomized design with three replications.

\subsection{Explant, Culture Media and Regeneration of Plantlets}

Meristem was used to regenerate for virus free plantlet production. From the regenerated virus free plantlets, plantlets again multiplied through rapid multiplication technique [8]. Required amount of MS medium [14] was prepared and supplemented with mentioned sucrose and BAP levels. Thus, prepared all groups of media were taken to separate test tubes and/or vials according to the number of treatments and replications. Then the test tubes/vials containing the media were sterilized by autoclaving. Stem segments having 1-5 nodes from plantlets of one month old which were collected from previous experiment were cultured for microtuberization. Single stem segments were placed to each test tube containing $10 \mathrm{ml}$ medium and 4-5 stem segments were placed to each vial containing $40 \mathrm{ml}$ medium. When placed in test tube, five test tubes were considered as one replication.

\subsection{Incubation}

The cultures were incubated at a temperature of $25 \pm 2^{\circ} \mathrm{C}$ at $16 \mathrm{hrs}$ photoperiod. Days to microtuber initiation were recorded. After two months of explantation, number of microtubers vial ${ }^{-1}$ was calculated on the basis of total number of vials per treatment and average weight of microtuber was calculated on the basis of total number of microtubers produced.

\subsection{Data Collection and Statistical Analysis}

After two months of explantation, data were recorded on 1) Days to microtuber initiation, ii) Number of microtubers vial ${ }^{-1}$, iii) Average weight of microtuber. Data were analyzed by statistical software MSTATC and means were adjudged by the Duncan's Multiple Range Test.

\section{Results and Discussions}

\subsection{Main Effect of Variety, Sucrose and BAP on Days to Micro-Tuberization, Number and Weight of Microtubers}

Between the varieties, Diamant required comparatively minimum days for microtuber initiation, which started at 6 days and continued up to 17 days, than that of Cardinal where the range was from 8 to 21 days. These findings were supported by Hossain and Sultana (1998) who reported that the response of variety to microtuberization was highly dependent on genetic factors. Microtuber number vial ${ }^{-1}$ did not vary significantly and the result showed that Diamant produced more number of microtubers (4.97) vial $^{-1}$ than that of Cardinal (4.19). The differences of average weight of microtuber were found non-significant where the average weight of microtubers were $120.39 \mathrm{mg}$ and $114.89 \mathrm{mg}$ in case of Diamant and Cardinal, respectively. Considering different concentrations of sucrose, the duration required for microtuber initiation varied with the variation of sucrose levels used in the culture media. Microtuber initiation was quickest (6-15 days) when 9\% sucrose was used and this duration gradually increased with both increasing and decreasing the level of sucrose. The present findings were directly in agreement with Jeoung-Lai et al. (1996) who reported that tuber induction medium combined with $9 \%$ sucrose promoted tuberization. Microtuber numbers vial $^{-1}$ increased with the increasing of sucrose level up to $9 \%$ and then again decreased. The highest number of microtubers vial $^{-1}$ was found in $9 \%$ sucrose (5.06) followed by $6 \%$ sucrose (4.78), whereas, the lowest was found with $3 \%$ sucrose (4.06). The highest average weight of microtuber $(137.31 \mathrm{mg})$ was found in $9 \%$ sucrose followed by $12 \%(119.17 \mathrm{mg})$ while the lowest $(99.01 \mathrm{mg})$ was in 3\% sucrose. The findings were similar to the findings of Jeoung-Lai et al. (1996) who found the heaviest microtubers with $9 \%$ sucrose. Among the three concentrations of BAP, duration required for microtuber initiation was 6-21 days at $2.5 \mathrm{mg} \mathrm{L}^{-1}$ BAP, 6-15 days at 5.0 $\mathrm{mg} \mathrm{L}^{-1}$ BAP and 7-20 days at $7.5 \mathrm{mg} \mathrm{L}^{-1}$ BAP. The highest number of microtubers vial ${ }^{-1}$ (5.38) was obtained at $5 \mathrm{mg} \mathrm{L}^{-1}$ BAP, whereas 2.5 and $7.5 \mathrm{mg} \mathrm{L}^{-1}$ BAP produced about similar number of microtubers (4.25 and 4.13 respectively) vial $^{-1}$. The present finding was supported by Yong et al. (1996) who reported that BAP promoted initiation and growth of microtubers. The highest average weight of microtuber (126.31 mg) was found in $5 \mathrm{mg} \mathrm{L}^{-1}$ BAP followed by $7.5 \mathrm{mg}$ $\mathrm{L}^{-1}$ BAP $(115.29 \mathrm{mg})$ and the lowest $(111.33 \mathrm{mg})$ was in 2.5 mg L ${ }^{-1}$ BAP. (Table 1) 
Table 1. Main effect of variety, sucrose and BAP on days to micro-tuberization, number and weight of microtubers at two months of ex-plantation.

\begin{tabular}{|c|c|c|c|c|}
\hline Treatments & & Days to micro tuberization & No. microtubers vial ${ }^{-1}$ of 5 plants & Average weight of microtuber (mg) \\
\hline \multirow[t]{2}{*}{ Variety } & Diamant & $6-17$ & $4.97 \mathrm{a}$ & $120.39 \mathrm{a}$ \\
\hline & Cardinal & $8-21$ & $4.19 \mathrm{a}$ & $114.89 \mathrm{a}$ \\
\hline \multirow{4}{*}{ Sucrose $(\%)$} & 3 & $9-17$ & $4.06 \mathrm{~b}$ & $99.01 \mathrm{~d}$ \\
\hline & 6 & $9-15$ & $4.78 \mathrm{ab}$ & $115.10 \mathrm{c}$ \\
\hline & 9 & $6-15$ & $5.06 \mathrm{a}$ & $137.31 \mathrm{a}$ \\
\hline & 12 & $10-21$ & $4.44 \mathrm{ab}$ & $119.17 \mathrm{~b}$ \\
\hline \multirow[t]{3}{*}{$\mathrm{BAP}\left(\mathrm{mg} \mathrm{L}^{-1}\right)$} & 2.5 & $6-21$ & $4.25 \mathrm{~b}$ & $111.33 \mathrm{c}$ \\
\hline & 5.0 & $6-15$ & $5.38 \mathrm{a}$ & $126.31 \mathrm{a}$ \\
\hline & 7.5 & $7-20$ & $4.13 b$ & $115.29 \mathrm{~b}$ \\
\hline CV (\%) & & - & 16.86 & 2.13 \\
\hline
\end{tabular}

Figures followed by same letter(s) are statistically similar as per DMRT

\subsection{Combined Effect of Variety and Sucrose on Days to Microtuber Initiation and Number and Weight of Microtubers}

Considering the variety and sucrose combinations, Diamant with $9 \%$ sucrose required comparatively minimum time (6-11 days) for microtuber initiation and maximum (12-17 days) with $12 \%$ sucrose (Table 2). Accordingly, Cardinal with $9 \%$ sucrose required 8-15 days and with $12 \%$ sucrose required 10-21 days for microtuber initiation. The highest number of microtubers vial $^{-1}(5.56)$ was found with Diamant at $9 \%$ sucrose followed by Diamant with $6 \%$ sucrose (5.33), whereas the lowest number (3.33) was obtained from Cardinal with 3\% sucrose (Table 2). Varietal difference on microtubers number with various concentrations of sucrose was observed by Warren and Shirlyn (2000) where number of microtubers increased with the increasing concentration of sucrose up to $16 \%$ in the variety Shepody. On the other hand, the highest average weight of microtuber (140.15 mg) was found in Diamant with $9 \%$ sucrose, whereas the lowest $(95.56 \mathrm{mg}$ ) was in Cardinal with 3\% sucrose.

\subsection{Combined Effect of Variety and BAP on Days to Microtuber Initiation and Number and Weight of Microtubers}

In case of variety and BAP combinations (Table 3), Diamant with $5.0 \mathrm{mg} \mathrm{L}^{-1}$ BAP required comparatively minimum (6-15 days) and Cardinal with $2.5 \mathrm{mg} \mathrm{L}^{-1}$ BAP required maximum (9-21 days) time for microtuber initiation. The maximum number of microtubers vial $^{-1}$ (5.58) was obtained from Diamant at $5 \mathrm{mg} \mathrm{L}^{-1}$ BAP, whereas the lowest number (3.67) was obtained from Cardinal at $7.5 \mathrm{mg} \mathrm{L}^{-1}$ BAP. Thus, the highest average weight of microtuber $(127.96 \mathrm{mg}$ ) was found in Diamant with $5 \mathrm{mg} \mathrm{L}^{-1}$ BAP followed by Cardinal with $5 \mathrm{mg} \mathrm{L}^{-1}$ BAP $(124.67 \mathrm{mg}$ ) while the lowest weight $\left(107.97 \mathrm{mg}\right.$ ) was found in Cardinal with $2.5 \mathrm{mg} \mathrm{L}^{-1}$ BAP.

\subsection{Combined Effect of Sucrose and BAP on Days to Microtuber Initiation and Number and Weight of Microtubers}

In case of sucrose and BAP combination (Table 4), 9\% sucrose performed minimum time (6-10 days) for microtuber initiation with $5.0 \mathrm{mg} \mathrm{L}^{-1}$ BAP followed by $2.5 \mathrm{mg} \mathrm{L}^{-1}$ BAP (6-12 days), whereas maximum time (15-20 days) was taken for $12 \%$ sucrose with $7.5 \mathrm{mg} \mathrm{L}^{-1}$ BAP. The highest number of microtubers vial $^{-1}$ (5.67) was obtained with $6 \%$ and $9 \%$ sucrose at $5 \mathrm{mg} \mathrm{L}^{-1}$ BAP followed by $12 \%$ sucrose with $5 \mathrm{mg}$ $\mathrm{L}^{-1} \mathrm{BAP}$ (5.17), whereas, the lowest number (3.33) was found at $3 \%$ sucrose with $7.5 \mathrm{mg} \mathrm{L}^{-1}$ BAP. The result was directly supported by Texeira and Pinto (1991). Average weight of microtuber $(150.38 \mathrm{mg})$ found to be the best in combination of $9 \%$ sucrose and $5 \mathrm{mg} \mathrm{L}^{-1} \mathrm{BAP}$, whereas, the lowest $(93.81 \mathrm{mg}$ ) was in $3 \%$ sucrose and $2.5 \mathrm{mg} \mathrm{L}^{-1}$ BAP. Variation in microtuber yield were also recorded by Al-Abdallat and Suwwan (2002) where $0,3,6$, and $9 \%$ sucrose and $5 \mathrm{mg} \mathrm{L}^{-1}$ BAP were used and better microtuber yield was obtained with $6 \%$ sucrose under complete dark condition. [Table 4]

\subsection{Combined Effect of Variety, Sucrose and BAP on Days to Microtuber Initiation and Number and Weight of Microtubers}

Considering all the three factors (Table 5), it was observed that the best combination was Diamant with $9 \%$ sucrose at 2.5 and at $5.0 \mathrm{mg} \mathrm{L}^{-1} \mathrm{BAP}$ which required minimum duration (6-8 days), whereas, Cardinal with $12 \%$ sucrose at $2.5 \mathrm{mg} \mathrm{L}^{-1}$ BAP required maximum duration (16-21 days) for microtuber initiation. On the other hand, the highest number of microtubers vial $^{-1}$ (6.00) was obtained from Diamant when cultured on media with $6 \%$ and $9 \%$ sucrose at $5 \mathrm{mg} \mathrm{L}^{-1}$ BAP. At the same time, the lowest number (2.00) was found in Cardinal cultured on media with $3 \%$ sucrose and $7.5 \mathrm{mg} \mathrm{L}^{-1}$ BAP (Plate 2). The present result may be considered as similar to the previous study of Estrada et al. (1986) where it was observed that MS medium with $5.0 \mathrm{mg} \mathrm{L}^{-1} \mathrm{BAP}, 8 \%$ sucrose and $500 \mathrm{mg} \mathrm{L}^{-1} \mathrm{CCC}$ would able to produce microtubers in a broad range of genotypes. Thus, the highest average weight of microtubers (152.01 mg) was found in Diamant with $9 \%$ sucrose and $5 \mathrm{mg} \mathrm{L}^{-1}$ BAP followed by Cardinal with $9 \%$ sucrose and $5 \mathrm{mg} \mathrm{L}^{-1}$ BAP (148.75 mg). Concomitantly, the lowest average weight of microtuber $(89.98 \mathrm{mg})$ was found in Cardinal with $3 \%$ sucrose and $2.5 \mathrm{mg} \mathrm{L}^{-1}$ BAP. (Table 5) 
Table 2. Combined effect of variety and sucrose on days to microtuber initiation and number and weight of microtubers after two months of inoculation.

\begin{tabular}{lllll}
\hline \multicolumn{2}{l}{ Combination } & Days to microtuber initiation & No. microtubers vial ${ }^{-1}$ of 5 plants & Average weight of microtuber (mg) \\
\cline { 1 - 3 } Variety & Sucrose (\%) & & \multicolumn{2}{c}{$102.44 \mathrm{e}$} \\
\hline Diamant & 3 & $9-15$ & $4.78 \mathrm{ab}$ & $118.55 \mathrm{c}$ \\
& 6 & $9-13$ & $5.33 \mathrm{ab}$ & $140.15 \mathrm{a}$ \\
& 9 & $6-11$ & $5.56 \mathrm{a}$ & $120.41 \mathrm{c}$ \\
Cardinal & 3 & $12-17$ & $4.22 \mathrm{bc}$ & $95.56 \mathrm{f}$ \\
& 6 & $10-17$ & $3.33 \mathrm{c}$ & $111.64 \mathrm{~d}$ \\
& 9 & $10-15$ & $4.22 \mathrm{bc}$ & $134.46 \mathrm{~b}$ \\
$\mathrm{CV}(\%)$ & 12 & $10-15$ & $4.56 \mathrm{ab}$ & $117.93 \mathrm{c}$ \\
\hline
\end{tabular}

Table 3. Combined effect of variety and BAP on days to microtuber initiation and number and weight of microtubers after two months of inoculation.

\begin{tabular}{|c|c|c|c|c|}
\hline \multicolumn{2}{|c|}{ Combination } & \multirow{2}{*}{ Days to microtuber initiation } & \multirow{2}{*}{ No. microtubers vial ${ }^{-1}$ of 5 plants } & \multirow{2}{*}{ Average weight of microtuber (mg) } \\
\hline Variety & BAP $\left(\mathrm{mg} \mathrm{L}^{-1}\right)$ & & & \\
\hline \multirow[t]{3}{*}{ Diamant } & 2.5 & $6-15$ & $4.75 \mathrm{ab}$ & $114.69 \mathrm{bc}$ \\
\hline & 5.0 & $6-15$ & $5.58 \mathrm{a}$ & $127.96 \mathrm{a}$ \\
\hline & 7.5 & $7-17$ & $4.58 \mathrm{ab}$ & $118.52 \mathrm{~b}$ \\
\hline \multirow[t]{3}{*}{ Cardinal } & 2.5 & $9-21$ & $3.75 \mathrm{~b}$ & $107.97 \mathrm{~d}$ \\
\hline & 5.0 & $8-15$ & $5.17 \mathrm{a}$ & $124.67 \mathrm{a}$ \\
\hline & 7.5 & $10-20$ & $3.67 \mathrm{~b}$ & $112.06 \mathrm{~cd}$ \\
\hline CV $(\%)$ & & - & 16.86 & 2.13 \\
\hline
\end{tabular}

Table 4. Combined effect of sucrose and BAP on days to microtuber initiation and number and weight of microtubers after two months of inoculation.

\begin{tabular}{lllll}
\hline Combination & & Days to microtuber initiation & No. microtubers vial ${ }^{-1}$ of 5 plants & Average weight of microtuber (mg) \\
\cline { 1 - 2 } Sucrose (\%) & BAP (mg L-1) & & & $93.81 \mathrm{~h}$ \\
& 2.5 & $12-16$ & $3.83 \mathrm{~cd}$ & $105.10 \mathrm{f}$ \\
& 5.0 & $9-12$ & $5.00 \mathrm{ab}$ & $98.10 \mathrm{~g}$ \\
6 & 7.5 & $11-17$ & $3.33 \mathrm{~d}$ & $106.36 \mathrm{f}$ \\
& 2.5 & $9-14$ & $4.50 \mathrm{bc}$ & $123.71 \mathrm{~d}$ \\
& 5.0 & $9-13$ & $5.67 \mathrm{a}$ & $115.22 \mathrm{e}$ \\
9 & 7.5 & $9-15$ & $4.17 \mathrm{bcd}$ & $128.93 \mathrm{bc}$ \\
& 2.5 & $6-12$ & $4.83 \mathrm{abc}$ & $150.38 \mathrm{a}$ \\
12 & 5.0 & $7-10$ & $5.67 \mathrm{a}$ & $132.61 \mathrm{~b}$ \\
& 7.5 & $13-21$ & $4.67 \mathrm{abc}$ & $116.23 \mathrm{e}$ \\
& 2.5 & $10-15$ & $3.83 \mathrm{~cd}$ & $126.07 \mathrm{~cd}$ \\
\hline
\end{tabular}

Figures followed by same letter(s) are statistically similar as per DMRT

Table 5. Combined effect of variety, sucrose and BAP on days to microtuber initiation and number and weight of microtubers after two months of inoculation.

\begin{tabular}{|c|c|c|c|c|c|}
\hline \multicolumn{3}{|c|}{ Treatment combination } & \multirow{2}{*}{ Days to micro-tuber initiation } & \multirow{2}{*}{$\begin{array}{l}\text { No. microtubers vial } \\
\text { plants }\end{array}$} & \multirow{2}{*}{$\begin{array}{l}\text { Average weight of microtuber } \\
(\mathrm{mg})\end{array}$} \\
\hline Variety & Sucrose (\%) & BAP $\left(\mathrm{mg} \mathrm{L}^{-1}\right)$ & & & \\
\hline \multirow[t]{12}{*}{ Diamant } & 3 & 2.5 & $12-15$ & $4.33 \mathrm{~b}-\mathrm{e}$ & $97.64 \mathrm{ij}$ \\
\hline & & 5.0 & $9-12$ & $5.33 \mathrm{abc}$ & $108.50 \mathrm{~h}$ \\
\hline & & 7.5 & $11-13$ & $4.67 \mathrm{a}-\mathrm{e}$ & $101.19 \mathrm{i}$ \\
\hline & 6 & 2.5 & $9-13$ & $5.00 \mathrm{a}-\mathrm{d}$ & $111.53 \mathrm{gh}$ \\
\hline & & 5.0 & $10-13$ & $6.00 \mathrm{a}$ & $124.86 \mathrm{~d}$ \\
\hline & & 7.5 & $9-11$ & $5.00 \mathrm{a}-\mathrm{d}$ & 119.26 ef \\
\hline & 9 & 2.5 & $6-8$ & $5.67 \mathrm{ab}$ & $130.36 \mathrm{c}$ \\
\hline & & 5.0 & $6-8$ & $6.00 \mathrm{a}$ & $152.01 \mathrm{a}$ \\
\hline & & 7.5 & $7-11$ & $5.00 \mathrm{a}-\mathrm{d}$ & $138.09 \mathrm{~b}$ \\
\hline & 12 & 2.5 & $13-14$ & 4.00 cde & $119.23 \mathrm{ef}$ \\
\hline & & 5.0 & $12-15$ & $5.00 \mathrm{a}-\mathrm{d}$ & $126.48 \mathrm{~cd}$ \\
\hline & & 7.5 & $15-17$ & $3.67 \mathrm{de}$ & $115.51 \mathrm{fg}$ \\
\hline \multirow[t]{7}{*}{ Cardinal } & 3 & 2.5 & $13-16$ & 3.33 ef & $89.98 \mathrm{k}$ \\
\hline & & 5.0 & $10-12$ & $4.67 \mathrm{a}-\mathrm{e}$ & $101.70 \mathrm{i}$ \\
\hline & & 7.5 & $15-17$ & $2.00 \mathrm{f}$ & $95.01 \mathrm{j}$ \\
\hline & 6 & 2.5 & $11-14$ & 4.00 cde & $101.19 \mathrm{i}$ \\
\hline & & 5.0 & $9-11$ & $5.33 \mathrm{abc}$ & $122.56 \mathrm{de}$ \\
\hline & & 7.5 & $13-15$ & 3.33 ef & $111.18 \mathrm{gh}$ \\
\hline & 9 & 2.5 & $9-12$ & $4.00 \mathrm{cde}$ & $127.51 \mathrm{~cd}$ \\
\hline
\end{tabular}




\begin{tabular}{|c|c|c|c|c|c|}
\hline \multicolumn{3}{|c|}{ Treatment combination } & \multirow{2}{*}{ Days to micro-tuber initiation } & \multirow{2}{*}{$\begin{array}{l}\text { No. microtubers vial }{ }^{-1} \text { of } 5 \\
\text { plants }\end{array}$} & \multirow{2}{*}{$\begin{array}{l}\text { Average weight of microtube } \\
\text { (mg) }\end{array}$} \\
\hline Variety & Sucrose (\%) & BAP $\left(\mathrm{mg} \mathrm{L}^{-1}\right)$ & & & \\
\hline & \multirow{6}{*}{ (2) } & 5.0 & $8-10$ & $5.33 \mathrm{abc}$ & $148.75 \mathrm{a}$ \\
\hline & & 7.5 & $10-15$ & $4.33 \mathrm{~b}-\mathrm{e}$ & $127.13 \mathrm{~cd}$ \\
\hline & & 2.5 & $16-21$ & $3.67 \mathrm{de}$ & $113.22 \mathrm{gh}$ \\
\hline & & 5.0 & $10-15$ & $5.33 \mathrm{abc}$ & $125.65 \mathrm{~cd}$ \\
\hline & & 7.5 & $17-20$ & $5.00 \mathrm{a}-\mathrm{d}$ & $114.91 \mathrm{fg}$ \\
\hline CV (\%) & & & & 16.86 & 2.13 \\
\hline
\end{tabular}

Figures followed by same letter(s) are statistically similar as per DMRT

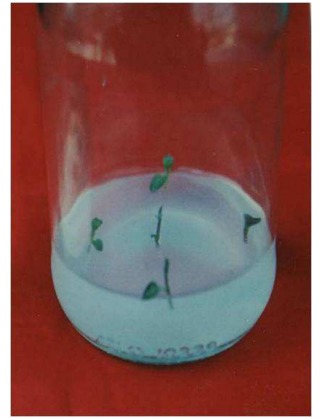

A. During explantation

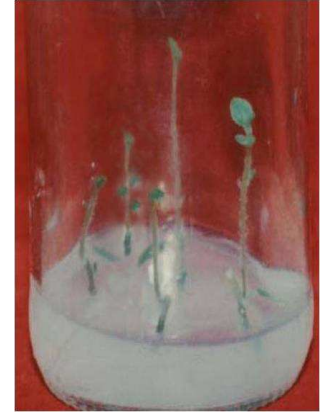

B. Fifteen days after explantation

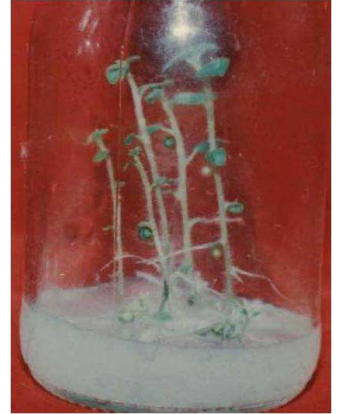

C. One month after explantation

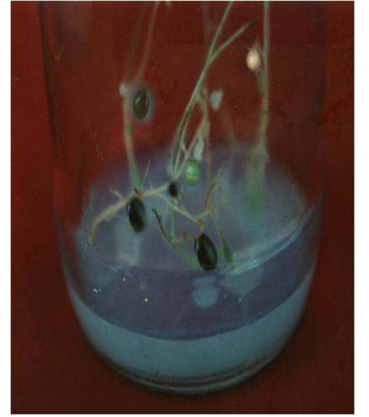

D. Two months after explantation

Plate 1. Microtuberization stages of potato cv. Diamant.

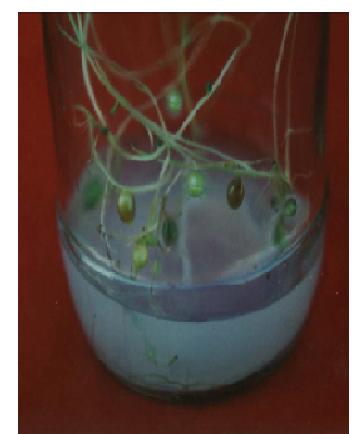

A. Diamant with $6 \%$ Sucrose and $5 \mathrm{mg} \mathrm{L}^{-1} \mathrm{BAP}$

Plate 2. Number of microtubers at two months of explantation under different treatments.

\section{Conclusion}

Microtuber production was affected by different levels of sucrose and 6-benzyl aminopurine (BAP). Genotypic variation was also found among the two genotypes regarding microtuber production. The best combination for rapid microtuber production of potato varieties was Diamant with $9 \%$ sucrose at $5 \mathrm{mg} \mathrm{L}^{-1}$ of 6-benzyl aminopurine. Hence the present protocol has the potential for the rapid multiplication of true-to-true type clones without changing the genetic fidelity.

\section{Acknowledgements}

The author expresses his deep sense of gratitude to United States Department of Agriculture (USDA) funded project \#99/22/USDA and thankful to the authority of Tuber Crop Research Centre (TCRC) of Bangladesh Agricultural Research Institute (BARI), Bangladesh for their help in

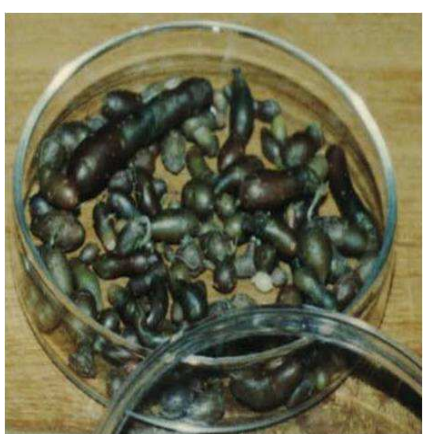

A. Cardinal

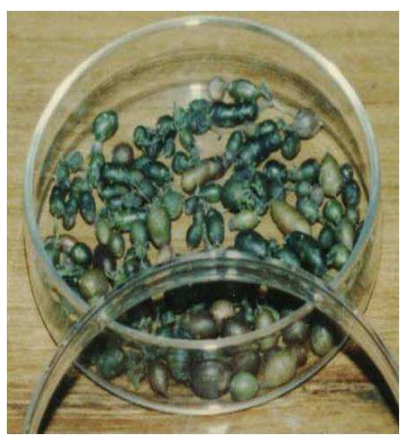

B. Diamant
Plate 3. Microtubers of two potato varieties after harvest.

supplying the seed tubers, several information and sharing the knowledge. It was a part of $\mathrm{PhD}$ research works. The author also thanks to all staffs of Biotechnology Laboratory, Department of Biotechnology, Bangladesh Agricultural University, Bangladesh.

\section{References}

[1] Al-Abdallat, A. K., and M. A. Suwwan. 2002. Interactive effects of explant, sucrose and CCC on microtuberization of 'Spunta' potato. Dirasat. Agril. Sci. 29: 19-27.

[2] Avetisov, V. A., O. S. Melik-Sarkisov and G. I. Sobolkova. 1989. Induction of microtuberization on regenerates from callus of potato. Sel'skokhozyaistvennaya Biologiya. 5: 26-28.

[3] Cui, C., F. F. F. He, J. C. Wang, Q. Y. Zhou, Y. X. Huang and D. B. Tang. 2001. Effects of photoperiod and carbon sources on the formation of microtubers of potato in vitro. J. Southwest Agril. Varsity. 23: 547-548. 
[4] Dodds, J. H., P. Tovar, R. Chandra, D. Estrella and R. Cabello. 1988. Improved methods for in vitro tuber induction and use of in vitro tubers in seed programs. In: Proc. Symp. on Improved Potato Planting Material, Asian Potato Assoc., Kunming, China, June, 1988. pp. 157-158.

[5] Estrada, R., P. Tovar and J. H. Dodds. 1986. Induction of in vitro tubers in a broad range of potato genotypes. Plant Cell Tiss. Org. Cult. 7: 3-10.

[6] Haque, M. I., N. B. Mila, M. S. Khan and R. H. Sarker. 1996. Shoot regeneration and in vitro microtuber formation in potato. Bangladesh J. Bot. 25: 87-93.

[7] Hossain, M. A., H. M. Faruquee, N. Islam, M. A. S. Miah and K. M. Nasiruddin. 2005. Agrobacterium-mediated transfer of PsCIPK salt tolerance gene in sugarcane variety Isd 35. Mol. biol. biotechnol. j. 3(1\&2): 1-3.

[8] Hossain, M. J. 1995. Effect of population density of cut shoot of potato on growth, tuber yield and multiplication rate. Trop. Sci. 35(2):161-166.

[9] Hossain, M. J. and N. Sultana. 1998. Effects of benzylaminopurine (BAP) and chloro choline chloride (CCC) on in vitro tiberization of potato. Bangladesh J. Agril. Res. 23: 685-690.

[10] Islam, M. S. 1995. Indigenous potato varieties of Bangladesh: Characterization by RAPD markers and production of virus free stock. Ph. D. Thesis, Dept. of Horticulture, Bangabandhu Sheikh Mujibur Rahman Agril. University, Gazipur, Bangladesh.

[11] Jeoung-Lai, C., S. M. Kang and Y. W. Choi. 1996. Effects of shoot culture and tuber inducing conditions on in vitro tuberization of potatoes. Proc., 4th Triennial Confc., Asian Potato Association. Philippines. pp. 186-190.

[12] Kabseog, Y. 2004. Relative importance of maltose and sucrose supplied during a 2-step potato microtuberization process. Acta Physiol. Plantarum. 26: 47-52.
[13] Liu, Z. L., Z. L. Wang, S. L. Wang, K. Gao. 2002. Effects of chlorobromoisocyanuric acid on culture of potato (Solanum tuberosum) plantlets in vitro. Chinese Potato J. 16(5): 288-290.

[14] Murashige, T., and F. Skoog. 1962. A revised medium for rapid growth and bioassays with tobacco tissue cultures. Physiologia Plantarum 15:473-497.

[15] Rashid, M. H., S. Akhter, M. Elias, M. G. Rasul and M. H. Kabir. 1993. Seedling tubers for ware potato production: Influence of size and plant spacing. Asian Potato J. 3: 14-17.

[16] Texeira, D. M. C. and J. E. B. P. Pinto. 1991. Minituberization of potatoes at different levels of $\mathrm{N}$, saccharose and BAP. Revista Brasileria de Figiologia Vegetal. 3 (3): 77-83.

[17] Warren, K. C. and E. C. Shirlyn. 2000. Modification of potato microtuber dormancy during induction and growth in vitro or ex vitro. Am. J. Potato Res. 77: 103-110.

[18] Yasmin, L. 2005. Effect of $\mathrm{N}$ and $\mathrm{K}$ on in vitro microtuberization of potato. M.S. Thesis, Dept. of Biotechnology., Bangladesh Agril. Univ., Mymensingh, Bangladesh. pp. 89.

[19] Yong, L., D. Huiruo, X. Xin, Y. Hongfu, J. Liping, L. Huan and Z. Ying. 1996. Changes in several endogenous phytohormones during in vitro tuberization in potato. In: E. T. Rasco and F. B. Aromin (Eds.). Asian Sweet Potato and Potato Res. and Development, Manila. July 1995-June 1996. 1: 30-37.

[20] Zakaria, M. 2002. Induction and performance of potato microtuber. Ph.D. Thesis, Dept. of Hort., Bangabandhu Sheikh Mujibur Rahman Agricultural University, Salna, Gazipur, Bangladesh.

[21] Zakaria, M., M. M. Hossain, M. A. K. Mian, T. Hossain and M. Z. Uddin. 2008. In vitro tuberization of potato influenced by benzyl adenine and chloro chline chloride. Bangladesh J. Agril. Rer. 33(3): 419-425. 